increase being in the afternoon and evening periods. At its maximum, which is during evening transmission time, the increase is very large, and in some surveys it almost doubles the number of visitors present.

Some of the visitors to viewer homes come as expected guests while others 'drop in' casually. With formal or 'expected' visiting, there is an increase in all four surveys, particularly those dealing with winter behaviour. With casual visiting, however, the increase is limited mainly to London (winter), some of the other surveys producing evidence even of slight reduction. There is a lot of variation in the effect of television according to the length of set ownership, but only with casual visiting is there any consistent trend; in this case it suggests a return towards pre-television level.

The investigators are to be commended not only for the clarity of their report but also for the way they hrve demonstrated the validity of their findings.

\title{
UNGULATES OF THE PARC NATIONAL ALBERT
}

A PAPER reporting the results of a study of the ecology of the twenty-two species of ungulates living in the Albert National Park in the eastern (Belgian) Congo, carried out from July 1957 to December 1959, forms fascicule I of the "Exploration du Parc National Albert" published by the Institut des Pares Nationaux du Congo Belge " Introduction a l'Ecologie des Ongulés du Parc National Albert", par F. Bourlière et J. Verschuren. Bruxelles, 1960). The report gives a full description of the various habitats that can be found in the $8,090 \mathrm{sq}$. $\mathrm{km}$. of the Park, with emphasis on their geographical, climatic, edaphic and botanical characters, and compares their present state with photographic records of thirty years ago. On the whole there has been no great change, the loss of tree cover in some places being compensated by increases elsewhere. A detailed consideration is given to the geographical distribution of the various species of ungulates (and the elephant) with special attention to their autoecology and food habits. Although many species are plentiful, three-the elephant, hippopotamus, and buffaloare the dominant species, and there is some evidence from a few marked animals that individuals tend to be surprisingly restricted to their territories.
Studies on the density of the ungulate populations were made by regular censuses, and population structure and dynamics are dealt with in separate chapters. During the past thirty years the population of different species has varied in different ways in the same environments. Elephants have increased by immigration, the numbers of hippopotamuses have remained stable, and despite epidemics of rinderpest there has been a spectacular increase in the buffalo population. Other species, such as the topi and the Uganda cob, have increased again after reaching a low level about 1940. Apart from epidemics of rinderpest affecting buffalo, and of anthrax affecting hippopotamus, a number of animals are frequently killed by lethal concentrations of carbon dioxide of volcanic origin. Competition for food in the various environments does not appear to play an important part among the ungulates of the Park.

The authors conclude that on the whole the open plains of the Albert National Park harbour the highest ungulate biomass ever found in Africa. Nevertheless, with the exception of the elephant, the species do not seem to exceed the carrying capacity of the environment. The report is illustrated with forty-nine plates of excellent and well-chosen photographs.

\section{IODIZED SALT AND ENDEMIC GOITRE}

T HE September issue of The Chronicle of the World Health Organization is devoted to endemic goitre (14, No. 9 ; September 1960). The importance of iodized salt as a means of control is well brought out, as are the problems of instituting programmes of mass prophylaxis because of difficulties in manufacturing suitable grades of iodized salt.

Inexpensive and comparatively simple processes are now available which are applicable to any of the usual methods of salt manufacture and give produets stable under exacting climatic conditions. Besides descriptions of the manufacturing methods, optimum dosages of iodized salt for individuals in different areas are reviewed.

The optimum level of iodization of salt depends on the average daily dose of iodine needed to prevent goitre in a community and on the average daily consumption of iodized salt per head. The available evidence suggests that, in endemic goitre areas, each person should receive a daily supplement of about $150 \mu \mathrm{gm}$. of iodine. In some areas, larger supplements (up to 300-400 $\mu \mathrm{gm}$. daily) appear to be necessary, presumably in order to counteract the effect of goitrogenic agents. The consumption per head of salt varies with racial, climatic and other factors; it is higher, for example, in tropical than in temperate climates. It is also necessary to take into account whether all food salt is to be iodized, including that used by food industries, or only table salt.

In the United States, Canada and most countries of Latin America, the level of iodization is based on an estimated average consumption of $6.5 \mathrm{gm}$. per head of table-salt each day, and is calculated to provide a daily supplement of $500 \mu \mathrm{gm}$. of iodine, or $650 \mu \mathrm{gm}$. of potassium iodide. The level is thus $1: 10,000$. In most European countries, much lower levels are used, calculated to supply only the 100 $150 \mu \mathrm{gm}$. of iodine per day estimated to be the body's actual physiological requirements. Thus, in Switzerland, where all food salt is iodized, the level is $1: 100,000$, while in the United Kingdom, where only table salt is iodized, the level is $1: 40,000$. Holman and MeCartney suggest that, for countries with a moderate goitre-rate, the most satisfactory level is 
probably 1 part potassium iodide to 20,000 parts of table salt, the level at present adopted in New Zealand. In countries with a high prevalence, the level of iodization should be increased to $1: 10,000$. In all events, the level fixed by the public health authorities should ensure that a minimum of $150 \mu \mathrm{gm}$. of iodine is available in the quantity of salt consumed daily per head, and where the dietary standard is low or there are other adverse factors, this amount should be increased to $300-400 \mu \mathrm{gm}$.

It is important to ensure not only that the salt has the required iodine content when it leaves the factory but also that no loss of iodine occurs in storage.

\section{BRADYKININ}

\section{Synthetic Bradykinin : its Biological Identity with Natural Pure Trypsin Bradykinin}

A BOUT twelve years after its discovery by 1 Rocha e Silva, Beraldo and Rosenfeld ${ }^{1}$ bradykinin was isolated, synthesized and its structure elucidated.

Rocha e Silva et al. first succeeded in preparing a strongly enriched preparation of bradykinin ${ }^{2}$. The next steps were due to Elliott, Lewis and Horton: the isolation of pure natural trypsin bradykinin ${ }^{3}$, the description of the pharmacological activity of the pure substance ${ }^{4}$ and, after degradation studies, proposal of a structure (Arg-Pro-Pro-Gly-Phe-SerPhe-Arg) ${ }^{5}$. Synthesis of the above-mentioned octapeptide yielded a compound which was practically inactive $e^{6-10}$. It was concludod that the proposed structure was incorrect. Other polypeptides containing the amino-acids of pure natural bradykinin were therefore systematically synthesized ${ }^{7,11}$ and biologically tested ${ }^{7,8}$ in our Laboratories. An octapeptide with a slightly different amino-acid sequence H-LArg-L-Pro-Gly-L-Phe-L-Ser-L-Pro-L-Pho-L-Arg-OH was found to possess bradykinin-like activity, but to a lesser degree ${ }^{7}, 8$. This prompted Boissonnas, Guttmann and Jaquenoud to synthesize a nonapeptide H-L-Arg-L-Pro-L-Pro-Gly-L-Phe-L-Ser-L-ProL-Phe-L-Arg-OH ${ }^{7,8,11}$, which in its biological activity and in its chemical, biochemical and biophysical properties was indistinguishable from natural bradykinin. We therefore stated ${ }^{7,8}$ that this nonapeptide was identical with bradykinin or closely related to it.

Having been informed of these results in a personal communication, Elliott et al. carried out new degrada. tion studies and were able to prove that natural bradykinin has, in fact, the same structure as the synthetic nonapeptide ${ }^{12}$.

The present investigation, a direct comparison of the synthetic nonapeptide with pure trypsin bradykinin, was undertaken to furnish further evidence that the two substances are identical.

Natural trypsin bradykinin (a sample of 100 $\mu \mathrm{gm}$. with an activity of $80 \mu \mathrm{gm}$. , which does not contain other biologically active peptide impuritios, kindly supplied by Dr. Lewis) and synthetic nonapeptide as trifluoracetate were compared for effect on isolated guinea pig ileum (Tyrode, $10 \mathrm{ml}$. bath, $37^{\circ}$; 4-point assay), isolated rat uterus (de Jalon, $10 \mathrm{ml}$. bath, $30^{\circ}$; animals pretreated with $0.2 \mathrm{mgm}$. stilbostrol, subcutaneous ; 4-point assay), blood pressure of the rabbit $(1 \cdot 6 \mathrm{gm}$. $/ \mathrm{kgm}$. urethane subcutaneous ; 4-point assay) and on capillary permeability in the guinea pig $(0.1 \mathrm{ml}$. of test solutions intracutaneously, animals pretreated with intravenous Evan's blue, for details see ref. 7). The results are givon in Table 1.

It can be seen from Table 1 that within the limits of the assay methods employed there is no difference
Table 1. Comparativg Evaluation of Blological Activity of SYNTGETIC AND NATURAL BRADYKININ

\begin{tabular}{|c|c|c|}
\hline Test & $\begin{array}{c}\text { Synthetic } \\
\text { nonapeptide }\end{array}$ & $\begin{array}{l}\text { Natural trypsin } \\
\text { bradykinin }\end{array}$ \\
\hline $\begin{array}{l}\text { Isolated guinea plg ileum } \\
\text { (mcan of } 11 \text { exps.: each } \\
\text { comprising } 4 \text { groups of } \\
4 \text { points } \pm . D . \text { ) } \\
\text { Isolated rat uterus (mean } \\
\text { of } 9 \text { exps.: each compris- } \\
\text { ing } 4 \text { to } 6 \text { groups of } 4 \\
\text { points } \pm S . D . \text {. } \\
\text { Rabbit blood pressure (mean } \\
\text { of } 4 \text { exps. : each compris- } \\
\text { ing } 2 \text { to } 4 \text { groups of } 4 \\
\text { points } \pm S . I .) \\
\text { Capillary permeability, } \\
\text { guinea pig (results from } \\
16 \text { animals) }\end{array}$ & $\begin{array}{c}89 \pm 13 \text { per cent } \\
10 \mathrm{ngm} . / 0 \cdot 1 \mathrm{ml} . \\
12 \times= \\
3 \times> \\
1 \times \times \\
1 \mathrm{ngm} / 0 \cdot 1 \mathrm{ml} . \\
11 \times= \\
4 \times> \\
1 \times< \\
0 \cdot 1 \mathrm{ngm} . / 0 \cdot 1 \mathrm{ml} . \\
\text { effects in } 9 \text { of } 16\end{array}$ & $\begin{array}{c}100 \text { per cent } \\
10 \text { ngm. } / 0.1 \mathrm{ml} . \\
12 \times= \\
3 \times 5 \\
1 \times> \\
1 \mathrm{ngm} .0 \cdot 1 \mathrm{ml} . \\
11 \times= \\
4 \times< \\
1 \times \times \\
0 \cdot 1 \mathrm{ngm.} / 0 \cdot 1 \mathrm{ml} . \\
\text { effects in } 9 \text { of } 16\end{array}$ \\
\hline
\end{tabular}

between the activity of the synthetic nonapeptide and trypsin bradykinin. We therefore conclude that our synthetic nonapeptide is identical with trypsin bradykinin.

The recent developments in bradykinin research present a rather unusual situation, since this naturally occurring potent polypeptide was synthesized ${ }^{7,8,11}$ before the complete structure of bradykinin was known.

\section{H. KonZETT* \\ E. STÜrRMER}

Pharmacological Laboratories, Sandoz, Ltd., Basle.

* Present address: Pharmakologisches Institut der Universität Innsbruck, Austria.

Rocha e Silva, M., Beraldo, W. T., and Rosenfeld, G., Amer. J. Physiol., 156, 261 (1949).

2 Rocha e Silva, M., in "Polvpeptides which affect Smooth Muscles and Blood Vessels", M, Schachter (Oxford, London, New York, Paris: Pergamon Press, 1960).

${ }^{3}$ Elliott, D. F., Lewis, G. P., and Horton, E. W., Biochem. J., 74, $15 P(1960)$.

Elliott, D. F., Horton, E. W., and Lewis, G. P., J. Physiol., 150, $6 P(1960)$. "Elliott, D. F., Lewis, G. P., and Horton, E. W., Biochem. $J .$, 76,

- Boissonnas, R. A., Guttmann, St., and Jaquenoud, P.-A., Helv. chim. Acta, 43, $1481(1960)$.

${ }^{7}$ Boissonnas, R. A., Guttmann, St.. Jaquenoud, P.-A., Konzett, H., and Stirmer, E., Experientia, is, $326(1960)$.

B Konzett, H., and Stürmer, E., Brit. J. Pharmacol. (in the press).

- Schwyzer, R., Rittel, W., Sieber, P., Kappeler, H., and Zuber, H., Helv. chim. Acto, 48, 1130 (1960).

${ }^{10}$ Nicolaides, E. D., De Wald, H. A., Shorley, P. G., and Collier, H. O. J., Nature, 187, $773(1960)$.

${ }^{11}$ Boissonnas, R. A., Guttmann, St., and Jaquenoud, P.-A., Helv, ehim, Acta, 43, $1349(1960)$.

${ }^{12}$ Elliott, D. F., Lewis, G. P., and Horton, E. W., Biochem. Biophys. Res. Comm., 3, 87 (1960). 